\title{
Genetic Transformation of Neisseria catarrhalis by Deoxyribonucleate Preparations having Different Average Base Compositions
}

\author{
By B. W. CATLIN aNd L. S. CUNNINGHAM \\ Marquette University School of Medicine, Milwaukee, \\ Wisconsin, U.S.A.
}

(Received 19 May 1964)

\begin{abstract}
SUMMARY
The base contents of deoxyribonucleate (DNA) preparations from 7 strains of Neisseria catarrhalis were determined chromatographically. Three non-overlapping classes were distinguished by mole $\%$ guanine + cytosine. These centred about the values $41 \%$ ( 2 strains), $42.3 \%$ (4 strains, including ATCC 8193), and 44.5\% (strain NCTC 4103). Each of the 7 strains was capable of undergoing genetic transformation. DNA preparations from spontaneous streptomycin-resistant mutants of all 7 strains elicited transformation of recipient strains in all 49 possible combinations. Results with this group, therefore, do not support the hypothesis that success in transferring genetic information between 2 strains requires identity of average DNA base contents.

Differences of reciprocal transformation frequencies and of 4 physiological characteristics (nitrate reduction, pigment production on vancomycin-containing agar, hydrolysis of gelatin, and growth at $\mathbf{2 8}^{\circ}$ ) appeared to separate 6 of the strains of Neisseria catarrhalis from the seventh (NCTC 4103), which may properly be named $N$. cinerea.
\end{abstract}

\section{INTRODUCTION}

The mucosa of the upper respiratory tract of humans provides microhabitats for a variety of bacteria including several potentially pathogenic species which are known to undergo genetic transformation. Dense populations are observed in nasopharyngeal or other secretions. The idea that genetic information may be transferred between such bacteria in their natural habitat has gained some support from in vitro demonstrations of transforming activity of extracellular deoxyribonucleate (DNA). DNA-containing cellular materials spontaneously liberated by cultures of Neisseria meningitidis, Streptococcus (Diplococcus) pneumoniae, as well as of the non-parasitic Bacillus subtilis, elicited transformation of recipients of the corresponding species (Catlin, 1960a; Ottolenghi \& Hotchkiss, 1960, 1962; Takahashi, 1962), or of related species (Catlin, 1960 b).

If unlimited transfer of genetic information were to occur between bacteria, one would expect the development ultimately of a continuous spectrum of differences. That there are relatively stable distinguishable bacterial taxa implies that barriers to gene flow exist, as Ravin (1961) has pointed out. One barrier recently recognized, which has been thought to be insurmountable, involves differences of DNA base composition. Results of an investigation of interspecific transformation of Neisseria 
provide one example (Catlin \& Cunningham, 1961). DNA preparations from representatives of six different species had transforming activity for recipient cells of all six; analyses of their base compositions showed that the content of guanine plus cytosine $(\mathrm{G}+\mathrm{C})$ was close to $\mathbf{5 0} \%$ for all. On the other hand, two transformable strains of $N$. catarrhalis did not undergo detectable transformation when exposed to transforming preparations from the other six neisserias, and their $\mathrm{G}+\mathrm{C}$ content was $41 \%$. This difference of base composition was thought to provide a possible physical basis for the genetic barrier.

Studies by Marmur and his associates of base composition, molecular hybrid formation, and transforming activities of DNA preparations from various species of Bacillus led them to propose that similarity of overall DNA base composition is a minimum requirement for DNA interaction and for genetic compatibility between different species (Marmur, Schildkraut \& Doty, 1961; Marmur, Seaman \& Levine, 1963). They noted in Haemophilus, as well as in Bacillus, that species which were genetically related had the same base composition, although they might show very different efficiencies of interspecific transformation.

Additional genetic material suitable for testing this hypothesis has been found in Neisseria catarrhalis. The investigation to be described here has revealed significant differences of average base composition among DNA preparations from 7 strains, 5 additional strains having been acquired since the previous study (Catlin \& Cunningham, 1961). Their $G+C$ contents ranged from 41 to $44.5 \%$. Contrary to expectation, each of the seven $N$. catarrhalis recipients was transformed by all of these DNA preparations.

Further studies of the range of transfer of genetic information were made with selected bacteria indigenous to the mucosa which bear some resemblance to Neisseria catarrhalis. The following communication presents results of transformation tests of moraxellas and allied organisms, and shows the application of transformation techniques to a particular problem of classification. A third communication will describe reciprocal transformations of $N$. catarrhalis and Moraxella nonliquefaciens.

\section{METHODS}

\section{Strains}

Seven strains of Neisseria catarrhalis were investigated: Ne 11, University of Rochester collection; Ne 13, New York State Department of Health; ATcc 8193, American Type Culture Collection; Ne 23, throat culture from a healthy student; N 9, University of Maryland collection; 8313, University of Maryland collection; NCTC 4103, National Collection of Type Cultures, London. Strains Ne 11 and Ne 13 have been described previously (Catlin \& Cunningham, 1961). Strains N 9 and 8313 were kindly provided by Sylvia G. Cary, Walter Reed Army Institute of Research, Washington.

When received each strain was streaked on an agar medium containing heart infusion and yeast extract (Difco) supplemented with ribonucleic acid, sodium glutamate, and calcium chloride (HIY-1 agar; Catlin \& Cunningham, 1961). One or more typical colonies were isolated and separately subcultured. Thereafter, to minimize population changes, all subcultures were made by streaking out organisms selected from 10 to 20 typical colonies. 
Strains were preserved at $-60^{\circ}$ in the following way. Masses of $18-\mathrm{hr}$ growth were transferred with an inoculation loop from HIY-1 agar to a number of small screw-cap vials which contained HIY broth $+0 \cdot 1 \%(\mathrm{w} / \mathrm{v})$ agar, and were immediately frozen. Organisms from a thawed suspension were subcultured daily on fresh HIY-lagar over a period not exceeding 1 week. Cultures were grown, usually at $35^{\circ}$, in a humidified water-jacketed incubator or an incubator-shaker (Model G27, New Brunswick Scientific Co. Inc., New Jersey).

Dihydrostreptomycin sulphate (Squibb; DHS) was used for all studies involving streptomycin-resistant (str-r) strains. Spontaneous str-r mutants were obtained from each Neisseria catarrhalis strain by the following procedure. The parent strain was cultivated at $35^{\circ}$ in $500 \mathrm{ml}$. flasks containing $50 \mathrm{ml}$. of heart infusion broth $+0.5 \%(\mathrm{w} / \mathrm{v}$ ) yeast extract (Difco). After 8-10 hr incubation with shaking, $100 \mathrm{ml}$. of additional broth was added together with DHS sufficient to give $500 \mu \mathrm{g}$. $/ \mathrm{ml}$. The culture was re-incubated for $16 \mathrm{hr}$ with shaking, and samples were plated in HIY-1 agar containing $500 \mu \mathrm{g}$. DHS $/ \mathrm{ml}$. A single isolated colony was picked, subcultured, and its identity established by morphological and cultural examination.

The strain designated NCTC 4103 str- $r 11$ is a transformant derived by exposing strain 4103 to DNA from Ne 11 str- $r$; a single isolated colony was picked from agar containing $500 \mu \mathrm{g}$. DHS $/ \mathrm{ml}$.

\section{Bacteriological characteristics}

Oxidase reaction. The method of Kovacs (1956) was used with 20-hr cultures. The tetramethyl- $p$-phenylenediamine dihydrochloride (Eastman) solution was prepared each day. This reagent was used, also, as a routine check of transformation test cultures, being poured sparingly on surface growth or introduced to subsurface colonies by stabbing through the semi-solid agar.

Catalase production. Vigorous evolution of gas was noted immediately after adding a drop of $3 \%(\mathrm{v} / \mathrm{v})$ solution of hydrogen peroxide to $20 \mathrm{hr}$ cultures on HIY-1 agar.

Gelatin hydrolysis. The method of Frazier given in the Manual of Microbiological Methods (1957, p. 158) was slightly modified to increase its sensitivity. The medium was heart infusion broth (Difco) with additions of $1 \%(\mathrm{w} / \mathrm{v})$ agar (Purified, Difco) and $0.4 \%(\mathrm{w} / \mathrm{v})$ gelatin (Fisher Scientific Co.). This was dispensed in $15 \mathrm{ml}$. amounts in flat-bottom Petri dishes (molded Pyrex, $100 \times 22 \mathrm{~mm}$.), and cultures were spotted on the surface over an area about $1 \mathrm{~cm}$. in diameter. Plates were incubated at $35^{\circ}$ for 7 days in a covered container with moist bibulous paper to minimize drying. The reagent $\left(15 \mathrm{~g} . \mathrm{HgCl}_{2}\right.$ dissolved in $100 \mathrm{ml}$. distilled water $+20 \mathrm{ml}$. concentrated $\mathrm{HCl}$ ) poured in a $10 \mathrm{ml}$. quantity on the medium precipitates unhydrolysed gelatin, resulting in a white opacity. Strong gelatinase producers were surrounded by wide clear zones (Staphylococcus aureus used as positive control). A test was considered to be positive, however, when the medium underlying the bacterial growth (swept off to allow the reagent to act) remained completely transparent.

Deoxyribonuclease production. This was detected by a plate method (Kay, 1954) similar to that described above for gelatin hydrolysis except that $0 \cdot 2 \%(\mathrm{w} / \mathrm{v})$ sodium deoxyribonucleate (Nutritional Biochemicals Corp.) was substituted for gelatin. The reagent, which precipitates unhydrolysed DNA, was added to plate cultures 
after incubation for 2-3 days. A transparent zone peripheral to bacterial growth indicated enzymic depolymerization of the DNA.

Tests of capacity to produce acid from carbohydrates. The following compounds were investigated: glucose, galactose, rhamnose, fructose, arabinose, xylose, maltose, sucrose, lactose. Sterile stock solutions (filtered through Millipore $\mathbf{0 . 4 5} \mu$ membranes) were added to the rich proteinaceous agar medium previously described (Catlin \& Cunningham, 1961) to give concentrations of $0.5 \%(\mathrm{w} / \mathrm{v})$. The possibility that slight acid production resulting from oxidative attack might be neutralized by alkali production, prompted the use of two additional media: (i) the low-peptone base of Hugh \& Leifson (1953) with the concentration of agar (Purified, Difco) increased to $0.7 \%(\mathrm{w} / \mathrm{v})$ to permit surface growth on agar slopes, and with aseptic addition of $1 \%(\mathrm{w} / \mathrm{v})$ carbohydrate; (ii) the ammonium-free sustaining medium of Elrod \& Braun (1942) with bromthymol blue indicator added, and aseptic addition of $1 \%(\mathrm{w} / \mathrm{v})$ carbohydrate; this was tubed in $1 \mathrm{ml}$. volumes and inoculated with $10^{10}-10^{11}$ cells removed from $20 \mathrm{hr}$ HIY-1 agar cultures. In addition, heart infusion agar slopes with bromthymol blue and $10 \%(\mathrm{w} / \mathrm{v})$ glucose or $10 \%(\mathrm{w} / \mathrm{v})$ lactose were used, as recommended for certain Gram-negative rods (Schaub \& Hauber, 1948). A carbohydrate-free control tube of each basal medium was inoculated with each strain. All media were incubated at $35^{\circ}$ for at least a week and inspected periodically for acid production.

Indole production. Heart infusion broth (Difco) was supplemented aseptically with filter-sterilized L-tryptophan to give $0 \cdot 1 \mathrm{mM}$. Cultures, sampled after incubation for 2 and 7 days, were tested for indole using Kovács reagent (Manual of Microbiological Methods, 1957, p. 156). Escherichia coli was used as positive control.

Urea hydrolysis. Urea agar base concentrate (Difco) was prepared according to the manufacturer's directions. The test and control agar slopes were streaked, incubated, and examined as described below for citrate agar.

Growth on citrate agar. Simmons citrate agar (Difco) slopes, streaked with a small inoculum from a 20 -hr HIY-1 agar culture, were incubated at $35^{\circ}$ for 1 week, and examined periodically for evidence of growth and alkali production. Klebsiella pneumoniae was used as positive control.

Response to antibiotics. Cultures diluted to contain about $10^{7}$ bacteria $/ \mathrm{ml}$. were spread on the surfaces of HIY-1 agar plates by using sterile cotton swabs. 'Sensi-discs' (Baltimore Biological Lab.) or 'Multidisks' (Consolidated Lab. Inc., Chicago Heights) containing the concentrations of antibiotics listed in Table 1 were placed on the agar, and the plates were incubated at $35^{\circ}$ for $20 \mathrm{hr}$. A strain was regarded as susceptible to the antibacterial action of the agent when the disc was surrounded by a clear zone of any radius exceeding $1 \mathrm{~mm}$., indicating inhibition of growth. Resistance was indicated by growth up to the margin of the disc.

Nitrate reduction. Nitrate broth was prepared by addition of $0 \cdot 1 \%(\mathrm{w} / \mathrm{v}) \mathrm{KNO}_{3}$ to heart infusion broth (Difco). Periodically during incubation at $35^{\circ}$ for 7 days, samples of the cultures were tested for nitrite with sulphanilic acid and dimethylalpha-naphthylamine reagents (Manual of Microbiological Methods, 1957, p. 153). Negative nitrite tests were examined for residual nitrate by adding zinc granules.

Nitrite disappearance. Required volumes of a $2 \%(\mathrm{w} / \mathrm{v}) \mathrm{KNO}_{2}$ solution were added to heart infusion broth (Difco) to give concentrations of $0.1 \%, 0.03,0.01$ and $0.005 \%$. An inverted insert vial was placed in each tube of nitrite broth before 
autoclaving. Cultures were inspected periodically for evidence of growth and accumulation of gas, and samples were tested for nitrite (reagents above).

\section{Deoxyribonucleate preparations}

A given str-r strain, subcultured on HIY-1 agar containing $500 \mu \mathrm{g}$. DHS $/ \mathrm{ml}$, was inoculated into litre quantities of HIY-1 broth $+200 \mu \mathrm{g}$. DHS $/ \mathrm{ml}$. contained in Fernbach flasks. After 16-20 hr incubation with shaking, the cultures (usually 2) were harvested in $500 \mathrm{ml}$. cups in a refrigerated centrifuge, washed once and resuspended in EDTA + $\mathrm{NaCl}$ solution (0.1 $\mathrm{m}$ ethylenediaminetetra-acetate in a solution of $0 \cdot 15 \mathrm{M}-\mathrm{NaCl}, \mathrm{pH}$ adjusted to $7 \cdot 3-7 \cdot 4)$, and frozen.

The bacterial suspension was thawed at $50^{\circ}$, transferred to room temperature, and stirred mechanically during lysis by 1-3\% dodecyl sodium sulphate (Matheson, Coleman \& Bell; twice recrystallized from hot ethanol) which was added as a $30 \%$ $(w / v)$ aqueous solution. Lysis, essentially complete in $0.5-3 \mathrm{hr}$, resulted in a partially transparent and viscous solution. (It may be noted that $\mathrm{s} 9$ and some other strains of Neisseria catarrhalis, in contrast to N. meningitidis previously described (Catlin, 1960 a), liberated a deoxyribonuclease capable of depolymerizing the transforming DNA when the process of lysis was carried out in a solution of $\mathrm{NaCl}+0.015 \mathrm{M}$ sodium citrate.) The lysate, transferred to a litre beaker, was rotated vigorously by hand in a horizontal plane while 1-2 volumes of 95\% ethanol was slowly added. The resulting fibrous precipitate usually could be lifted out; occasionally centrifugation was required.

The nucleate fibres were dissolved in $\mathrm{EDTA}+\mathrm{NaCl}$ solution (with added $\mathrm{NaCl}$ to give a final concentration of $1 \mathrm{M}$ ) with stirring at $5^{\circ}$. This solution was clarified by centrifugation $\left(32,000 \mathrm{~g} ; 3^{\circ} ; 110 \mathrm{~min}.\right)$, and fibres precipitated with ethanol, as before, were lifted immediately from the fluid in which a flocculent precipitate was forming. These were washed in $75 \%(\mathrm{v} / \mathrm{v})$ ethanol, drained, and redissolved in EDTA + NaCl solution. Suggestions concerning a desirable range of DNA concentration are given by Marmur (1961). The nucleate was partially deproteinized with dodecyl sodium sulphate (step 1, described in Catlin \& Cunningham, 1958), and the ethanol-precipitated fibres were dissolved again in EDTA $+\mathrm{NaCl}$ solution, and subjected to centrifugation and reprecipitation. Digestion with crystalline ribonuclease (Worthington Biochemical Corp.) done out as described by Marmur (1961), except that the enzyme solution $(5 \mathrm{mg} . / \mathrm{ml}$. in $0.15 \mathrm{M}-\mathrm{NaCl}$ ) was boiled for $5 \mathrm{~min}$. before use. Thereafter, the DNA preparation was subjected to two further steps of deproteinization with dodecyl sulphate, each followed by an additional step of centrifugation of the DNA solution (in $\mathrm{M}-\mathrm{NaCl}$ ) for $110 \mathrm{~min} .\left(32,000 \mathrm{~g} ; 3^{\circ}\right.$ ), and reprecipitation of fibres with 1-2 volumes of ethanol. Sterilized for 3-4 hr in $\mathbf{7 5} \%$ $(\mathrm{v} / \mathrm{v})$ ethanol, the drained fibres finally were dissolved in sterile $0 \cdot 15 \mathrm{M}-\mathrm{NaCl}$ solution. Concentration of DNA was determined by the diphenylamine reaction (Dische, 1955).

\section{Analysis of the base composition of $D N A$ preparations}

RNA was assayed by the method of Pesez as modified for quantitative use by Zamenhof \& Chargaff (Zamenhof, 1957), except that preliminary drying of the sample was omitted. Samples submitted to base analysis showed not more than 3.7 \% RNA. 
The DNA samples were hydrolysed as described by Wyatt \& Cohen (1953). Instead of an oil bath, a Slaco test-tube heater (Hallikainen Instruments, Berkeley, Cal.), set at $175^{\circ}$, was used to heat the sealed ampoules, which were made from ignition tubes $(10 \times 70 \mathrm{~mm}$.). Safety shields were dispensed with, but the hydrolysates were frozen before opening to decrease the internal pressure which develops. Bases were then determined as described by Wyatt (1951), except that the differential extinction method of spectrophotometric assay was used (Vischer \& Chargaff, 1948), the coefficients being given by Bendich (1957). Replicate determinations agreed within $5 \%$.

\section{Transformation test}

A quantitative method developed for investigating transformation of Neisseria to streptomycin resistance has been described in detail (Catlin, 1960 a; Catlin \& Cunningham, 1961). It was used with only minor changes. A physiologically active population for use as recipient was obtained by twice subculturing the parent strain on HIY-1 agar at about 12-hr intervals. Bacteria taken from the second subculture $\left(35^{\circ}\right.$ for $\left.11-12.5 \mathrm{hr}\right)$ were suspended in HI-1 broth $\left(30^{\circ}\right)$ to give a slight visible turbidity (c. 1-2 $\times 10^{7}$ bacteria/ml.). A further dilution (in accordance with expected competence of the strain) was prepared and used immediately. Equal volumes $(1.5 \mathrm{ml}$.) of recipient suspension and DNA solution (final concentration, $10 \mu \mathrm{g} . / \mathrm{ml}$.) were mixed and incubated at $30^{\circ}$. After $30 \mathrm{~min}$., unbound transforming DNA was inactivated by addition of sterile crystalline deoxyribonuclease (Catlin, 1960a). A sample of the population taken at this time was suitably diluted and plated to determine the total number of bacteria/ml. Each reaction mixture was then assayed to determine the number of transformants $/ \mathrm{ml}$. For this, a sample (diluted in broth if necessary) was mixed with HIY-1 soft agar $\left(0.7 \%\right.$, w/v) kept fluid at $44^{\circ}$; immediately the entire volume was pipetted in $4 \mathrm{ml}$. samples on the surfaces of $8 \mathrm{HIY}-1$ hard agar $(1.4 \%, \mathrm{w} / \mathrm{v})$ plates. The plates were promptly incubated at $35^{\circ}$ without stacking. A soft agar overlay containing dihydrostreptomycin (a concentration sufficient to give $500 \mu \mathrm{g}$. DHS $/ \mathrm{ml}$. after diffusion) was added $5-7 \mathrm{hr}$ after the time of initial exposure of bacteria to DNA: $5 \mathrm{hr}, \mathrm{Ne} 11 ; 6 \mathrm{hr}$, all other strains, routinely; $7 \mathrm{hr}$, some tests of the slow-growing strains Ne 13 and NCTC 4103. Transformant colonies were counted after incubation at $35^{\circ}$ for 4-6 days.

Certain precautions were observed routinely. A control test with deoxyribonuclease-inactivated DNA was included in each experiment to reveal possible $s t r-r$ mutants. These were not encountered with the population densities employed. The remnant of the broth dilution of DNA prepared for each test was incubated as a sterility control. The identity of selected transformant colonies was confirmed by microscopic examination and oxidase reaction.

Absence of aggregation cocci is essential for accurate determination of $\%$ transformation. To obtain a general impression of the reliability of tests with a given strain, a wet mount of coccal suspension was prepared soon after mixing with DNA. In all tests with strains 8313, N9, and ATCC 8193, microscopic examination revealed that more than $85 \%$ of the presumptive colony-forming units (100 counted) were single or paired cocci and aggregates numbering more than 3-4 were rare. Suspensions of Ne 13 and NCTC 4103 were somewhat less homogeneous, containing up to 5\% aggregates having 5-8 cocci. Suspensions of strains $\mathrm{Ne} 11$ and $\mathrm{Ne} 23$ 
contained the most clumps: often $50 \%$ single and paired cocci, and 5-20\% aggregates of more than 8 cocci. Therefore, estimates of \% transformation of $\mathrm{Ne} 11$ and $\mathrm{Ne} 23$ were too high. As an experiment with any given recipient included tests of all transforming preparations, however, results were affected equally by aggregation.

\section{RESULTS}

Bacteriological characterization. All 7 strains were Gram-negative cocci. Cocci tended to occur in pairs with adjacent sides flattened, and their division was typical of that described for Neisseria (e.g. Murray \& Truant, 1954; Piéchaud, 1961). Growing diplococci appeared to increase in width, and division occurred in a plane perpendicular to the previous plane of division.

\section{Table 1. Characteristics of strains of Neisseria catarrhalis}

\begin{tabular}{|c|c|c|c|c|c|c|c|}
\hline Reaction or test* & Ne 11 & Ne 13 & $\begin{array}{c}\text { ATCC } \\
8193\end{array}$ & $\mathrm{Ne} 23$ & $\mathbf{N} 9$ & 8813 & $\begin{array}{c}\text { NCTC } \\
4103\end{array}$ \\
\hline Oxidase reaction & + & + & + & + & + & + & + \\
\hline Catalase production & + & + & + & + & + & + & + \\
\hline Deoxyribonuclease production & + & + & + & + & + & + & + \\
\hline $\begin{array}{l}\text { Acidification of medium } \\
\text { containing carbohydrate }\end{array}$ & - & - & - & - & - & - & - \\
\hline Indole production & - & - & - & - & - & - & - \\
\hline Urea hydrolysis & - & - & - & - & - & - & - \\
\hline Growth on citrate agar & - & - & - & - & - & - & - \\
\hline $\begin{array}{l}\text { Response to antibiotics } \\
\text { Penicillin }(2 \text { units) } \\
\text { Streptomycin }(2 \mu \mathrm{g} .) \\
\text { Tetracycline }(5 \mu \mathrm{g} .) \\
\text { Oleandomycin }(2 \mu \mathrm{g} .) \\
\text { Neomycin }(5 \mu \mathrm{g} .) \\
\text { Chloramphenicol (5 } \mu \mathrm{g} .) \\
\text { Erythromycin }(2 \mu \mathrm{gg}) \\
\text { Novobiocin }(5 \mu \mathrm{g} .) \\
\text { Kanamycin }(5 \mu \mathrm{g} .) \\
\text { Vancomycin }(30 \mu \mathrm{g} .) \\
\text { Vancomycin }(5 \mu \mathrm{g} .)\end{array}$ & $\mathbf{s}$ & $\mathbf{R}$ & $\mathbf{R}$ & $\mathbf{R}$ & $\mathbf{S}$ & $\mathbf{R}$ & $\mathbf{R}$ \\
\hline Nitrite disappearance & + & + & + & + & + & + & + \\
\hline Nitrate reduction & + & + & + & + & + & + & - \\
\hline Production of diffusible pigment & - & - & - & - & - & - & + \\
\hline Gelatin hydrolysis & + & + & + & + & + & + & - \\
\hline
\end{tabular}

* See Methods for details and for carbohydrates tested. Symbols: +, positive results; - , negative results; $S$, susceptible; $R$, resistant.

Each strain was examined at least twice: when first received, and later when the entire group had been collected. Most of the tests (Table 1) did not reveal significant differences among the strains. Thus, all showed strong deoxyribonuclease activity. All were susceptible to the antibacterial action of 9 of the 10 antibiotics tested. Professor M. J. Pelczar, Jr. earlier noted (personal communication) that neisserias are typically resistant to low concentrations of vancomycin. In confirma- 
tion of that observation, all 7 of the strains examined here were resistant to vancomycin applied in discs containing $5 \mu \mathrm{g}$., but were susceptible to $30 \mu \mathrm{g}$.

Potassium nitrite at concentrations of 0.1 or $0.03 \%$ inhibited growth of all strains, However, all tolerated $0.005 \% \mathrm{KNO}_{2}$, and growth of $\mathrm{Ne} 11$ and ATcc 8193 occurred in $0.01 \%$. Nitrite disappeared within a 5 day incubation period from all visibly turbid cultures; no gas accumulated in inverted insert vials.

Table 2. Guanine + cytosine content of transforming $D N A$ preparations from Neisseria catarrhalis strains

\begin{tabular}{|c|c|c|c|}
\hline \multirow[b]{2}{*}{ Source of DNA } & \multicolumn{3}{|c|}{ Mole $\% \mathbf{G}+\mathbf{C}$ from } \\
\hline & Chromatography & $\mathbf{T m}$ & Density \\
\hline $\mathrm{Ne} 11$ str-r & $40 \cdot 7 *, 41 \cdot 3$ & $41 \dagger$ & - \\
\hline Ne 13 str-r & $40 \cdot 1 *$ & - & $42 \ddagger, 40 \cdot 6 \S$ \\
\hline Ne 13 str-r 11 & $41 \cdot 3^{*}$ & - & - \\
\hline ATCC 8193 str-r & $42 \cdot 2,42 \cdot 3$ & - & - \\
\hline Ne 23 str-r & $42 \cdot 1,42 \cdot 2$ & - & - \\
\hline N 9 str-r & $42 \cdot 3,43 \cdot 0$ & - & - \\
\hline 8313 str-r & $42 \cdot 1,42 \cdot 4$ & - & - \\
\hline NCTC 4103 str-r & $44 \cdot 4,44 \cdot 4,45 \cdot 1$ & 一 & $43 \cdot 2 \S$ \\
\hline NCTC 4103 str-r 11 & $44 \cdot 6$ & - & - \\
\hline
\end{tabular}

Four characteristics served to differentiate strain NCTC 4.103 from the other 6 strains, which formed a homogeneous group: (i) NCTC 4103 did not reduce nitrate to nitrite during 7 days incubation; the others reduced nitrate within $20 \mathrm{hr}$; (ii) cultures of 4103 on HIY-1 agar developed a yellowish-tan coloration, presumably a water-soluble pigment; this was usually slightly visible in heavily streaked areas after incubation for $24 \mathrm{hr}$, and gradually diffused through the agar; pigment production was intense on HIY agar containing $5 \mu \mathrm{g}$. vancomycin $/ \mathrm{ml}$.; (iii) weak proteolytic activity of all strains except NCTC 4103 was detected by hydrolysis of gelatin in that part of the medium directly under the bacterial growth; (iv) on HIY-1 agar slopes streaked in duplicate with each strain, and incubated at $28^{\circ}$ and $36^{\circ}$, growth-retardation at $28^{\circ}$ was more conspicuous for NCTC 4103 than for the other strains.

Base content. Analyses of the over-all base composition of the DNA preparations showed the expected equivalence between adenine and thymine, and between guanine and cytosine. Therefore, values are given only for

$$
\text { mole } \% \mathbf{G}+\mathbf{C}(=\mathbf{G}+\mathbf{C} / \mathbf{A}+\mathbf{T}+\mathbf{G}+\mathbf{C}) \text {. }
$$

Table 2 lists separately the results of independent determinations, and gives some analytical values obtained by other investigators for the same DNA preparations. Three distinguishable classes were found among these 7 strains. $\mathbf{G}+\mathrm{C}$ values for strains $\mathrm{Ne} 11$ and $\mathrm{Ne} 13$ averaged $41 \%$. Values for strain NCTC 4103 were significantly higher (about $\mathbf{4 4 . 5 \%}$ ), and the str-r strains were indistinguishable, although one was derived by spontaneous mutation and the second by transformation (with 
DNA from Ne 11 str-r). The third class, the 4 remaining strains, was intermediate (average $42.3 \%$ ) and showed no overlap with either of the other classes.

Transformation. Transforming activity of the DNA preparations was examined in at least three separate experiments with each recipient, in view of the cellular aggregation of some strains (Methods). Results of single experiments with 6 of the strains are given in Table 3 . Transformation of strain 8313 was highly reproducible. On the other hand, up to threefold differences of $\%$ transformation were found with $\mathrm{Ne} 11$ (the values given are from the experiment showing least aggregation). In general, however, the ratios of \% transformation by DNA from the str-r strain corresponding to the recipient to \% transformation by any other DNA preparation were reproducible in experiments with these 6 strains.

Table 3. Transforming activity of $D N A$ preparations from strains of Neisseria catarrhalis

\begin{tabular}{|c|c|c|c|c|c|c|}
\hline \multirow[b]{3}{*}{ Source of DNA } & \multicolumn{6}{|c|}{ Recipient strain } \\
\hline & \multicolumn{6}{|c|}{ ( $\%$ transformation) } \\
\hline & $\mathrm{Ne} 11$ & ATcC 8193 & Ne 23 & N 9 & 8313 & NCTC 4103 \\
\hline Ne 11 str-r & $5 \cdot 38$ & $\mathbf{1 \cdot 6 9}$ & 8.99 & $1 \cdot 22$ & $\mathbf{2 \cdot 6 9}$ & $0 \cdot 025$ \\
\hline $\mathrm{Ne} 13$ str-r & $3 \cdot 79$ & $0 \cdot 50$ & $6 \cdot 77$ & 0.90 & $1 \cdot 53$ & 0.012 \\
\hline ATCC $8193 s t r-r$ & $4 \cdot 90$ & $2 \cdot 00$ & $8 \cdot 77$ & 0.98 & $\mathbf{3 \cdot 5 8}$ & 0.011 \\
\hline Ne 23 str-r & $4 \cdot 99$ & $1 \cdot 26$ & $11 \cdot 08$ & $1 \cdot 21$ & $3 \cdot 18$ & 0.011 \\
\hline N 9 str $-r$ & $4 \cdot 51$ & $1 \cdot 33$ & $6 \cdot 30$ & $1 \cdot 14$ & $3 \cdot 72$ & 0.242 \\
\hline 8313 str-r & $\mathbf{3} \cdot 78$ & $\mathbf{1 \cdot 2 4}$ & $6 \cdot 54$ & $1 \cdot 09$ & $4 \cdot 71$ & $0 \cdot 006$ \\
\hline NCTC $4103 s t r-r$ & $0 \cdot 06$ & $0 \cdot 033$ & $0 \cdot 27$ & 0.011 & $0 \cdot 69$ & $2 \cdot 492$ \\
\hline NCTC 4013 str-r 11 & $1 \cdot 65$ & $0 \cdot 67$ & $4 \cdot 07$ & $0 \cdot 26$ & $\mathbf{2 \cdot 2 7}$ & $1 \cdot 078$ \\
\hline
\end{tabular}

Erratic results were obtained in tests of strain Ne 13 recipient cocci with DNA from $\mathrm{Ne} 13$ str-r. The portion of the treated population which attained resistance to $500 \mu \mathrm{g}$. DHS $/ \mathrm{ml}$. varied from 0.02 to $5 \%$ in separate tests. Transformation by DNA preparations from strains $\mathrm{N} 9$ and 8313 frequently was too low to be detected, as previously noted (Catlin, 1963, Microbiol. Genet. Bull. 19, 5). However, when the challenge dose was $25 \mu \mathrm{g} . \mathrm{DHS} / \mathrm{ml}$., transformation was $0.1 \%$ or higher in tests of DNAs from all of the strains except NCTC 4103, which elicited $0.01 \%$ transformation. Clearly, then, genetic information involving the str-r determinant could be transferred successfully, although test conditions required for reliable quantitative assay of high-degree resistance have not been found for strain $\mathrm{Ne} 13$.

Results of the transformation tests suggest that strains $\mathrm{Ne} \mathrm{11,} \mathrm{Ne} \mathrm{13,} \mathrm{ATCC} \mathrm{8193,}$ $\mathrm{Ne} 23, \mathrm{~N} 9$, and 8313 are closely related. On the other hand, this group can be differentiated from strain NCTC 4103 by the distinctly lower frequencies of reciprocal transformation. The DNA preparation from the transformant strain NCTC 4103 $s t r-r 11$ elicited transformation of the group of 6 strains at intermediate frequencies, indicating increased molecular homology (Marmur, Seaman \& Levine, 1963; Catlin, 1964).

\section{DISCUSSION}

The hypothesis that similarity of guanine + cytosine $(G+C)$ content is a minimum requirement for genetic compatibility among different species has predictive value (Marmur, Seaman \& Levine, 1963). However, the findings with Neisseria catarrhalis illustrate the fact that DNA preparations may elicit genetic transformation in spite 
of apparently significant differences of average $\mathrm{G}+\mathrm{C}$ content of the donor and recipient strains. Presumably these strains possess homologies of nucleotide sequence, which are believed to be required for successful transformation, as well as some degree of heterogeneity of base composition. This possibility was recognized (e.g. Marmur et al. 1961), but in general the analytical results obtained with physical methods suggested that a given microbial DNA has a relatively narrow range of base composition, whereas the mean $\mathbf{G}+\mathbf{C}$ content of DNAs from all microbial species varies widely (from about 25 to $75 \%$ ). Moreover, intramolecular heterogeneity of base composition was thought to be relatively low (e.g. Sueoka, Marmur \& Doty, 1959). These findings were the basis of the expectation that few or no base sequence homologies would occur in two DNA preparations whose average base composition differed very significantly. Recent evidence suggests that intramolecular heterogeneity in pneumococcal DNA (Guild, 1963) may be greater than earlier estimated. The $N$. catarrhalis findings presented here illustrate the difficulty of making specific inferences concerning genetic homology solely on the basis of average $\mathbf{G}+\mathbf{C}$ data. With the development of new methods for detecting nucleotide sequence homologies (e.g. McCarthy \& Bolton, 1963; and discussion in Marmur, Falkow \& Mandel, 1963), average base composition data can be relieved of the burden of application at the fine-structure level.

Bacteriological tests adequate to reveal subgroups within the 'non-saccharolytic Neisseria' are rarely used. Early workers described a number of types of $N$. catarrhalis largely distinguished on the basis of colonial morphology. An organism described in 1906 by von Lingelsheim, and designated $N$. pharyngis cinerea in Topley and Wilson's Principles (1955), has been considered to be merely a variety of $N$. catarrhalis. The Subcommittee on the family Neisseriaceae (1954) noted that $N$. catarrhalis had not been the subject of any special study because it offered fewer complications than some of the other species to students of the genus. Berger \& Paepcke (1962) investigated 30 non-saccharolytic strains from the human nasopharynx, using a variety of methods, including precipitin tests, utilization of organic acids, growth at $22^{\circ}$, action on nitrates and nitrites, and pigment production. They concluded that their strains could be divided into two distinct groups corresponding to $N$. catarrhalis and $N$. cinerea.

Analyses of additional Neisseria catarrhalis strains will be required to determine the limits of the range of DNA base content, and whether strains exist which have $\mathrm{G}+\mathrm{C}$ values intermediate between the three classes $(41,42 \cdot 3$, and $44.5 \%)$ indicated by the data of Table 2. In spite of the reproducible differences of $\% \mathbf{G}+\mathrm{C}$, strain $\mathrm{Ne} 11$ and the group of 4 strains (ATCC 8193, Ne 23, N 9, and 8313) were not separable on the basis either of bacteriological characteristics (Table 1) or of transformation frequencies involving the str-r marker (Table 3). Differences may be revealed later, however, by investigation of other enzymic activities and additional genetic markers. On the other hand, strain NCTC 4103 is separable from the other 6 strains on the basis of differences of 4 physiological characters and of reciprocal transformation frequencies. Except that nitrite disappearance was not accompanied by gas formation, strain NCTC 4103 appears to correspond to $N$. cinerea, as characterized by Berger \& Paepcke (1962); 24 of their $27 N$. cinerea strains produced gas from nitrite. The 6 other strains are typical of $N$. catarrhalis. Interestingly, Berger \& Paepcke (1962) concluded from their bacteriological study and survey of the litera- 
ture that the frequency of isolation of these organisms has changed. N.catarrhalis which was considered to be a common inhabitant of the nasopharynx before 1928 is now comparatively rare, whereas the incidence of $N$. cinerea is believed to have increased.

We thank Professor Walter R. Guild for communicating results of density determinations on two DNA preparations. We acknowledge the competent technical assistance of Mrs Mary Donahue in performing the base analyses. This investigation was supported by research grants AI 02353-05 PC and CA 02128-09 PC from the National Institutes of Health, U.S. Public Health Service.

\section{REFERENCES}

Bendich, A. (1957). Methods for characterization of nucleic acids by base composition. In Methods in Enzymology, 3, 715. Ed. by S. P. Colowick \& N. O. Kaplan. New York: Academic Press.

Berger, U. \& Paepcke, E. (1962). Untersuchungen über die asaccharolytischen Neisserien des menschlichen Nasopharynx. Z. Hyg. Infekt.-Kr. 148, 269.

Catlin, B. W. $(1960 a)$. Transformation of Neisseria meningitidis by deoxyribonucleates from cells and from culture slime. J. Bact. 79, 579.

CAtrin, B. W. (1960b). Interspecific transformation of Neisseria by culture slime containing deoxyribonucleate. Science, 131, 608.

CAtlin, B. W. (1964). Reciprocal genetic transformation between Neisseria catarrhalis and Moraxella nonliquefaciens. J. gen. Microbiol. 37, 369.

Catlin, B. W. \& Cunningham, L. S. (1958). Studies of extracellular and intracellular bacterial deoxyribonucleic acids. J. gen. Microbiol. 19, 522.

Cathin, B. W. \& Cunningham, L. S. (1961). Transforming activities and base contents of deoxyribonucleate preparations from various neisseriae. J. gen. Microbiol. 26, 303.

Dische, Z. (1955). Color reactions of nucleic acid components. In The Nucleic Acids, 1 , 285. Ed. by E. Chargaff \& J. N. Davidson. New York: Academic Press.

Elrod, R. P. \& Braun, A. C. (1942). Pseudomonas aeruginosa: its role as a plant pathogen. J. Bact. 44, 633.

Guild, W. R. (1963). Evidence for intramolecular heterogeneity in pneumococcal DNA. J. mol. Biol. 6, 214.

Hugh, R. \& Leifson, E. (1953). The taxonomic significance of fermentative versus oxidative metabolism of carbohydrates by various Gram-negative bacteria. $J$. Bact. 66, 24 .

KAY, D. (1954). The deoxyribonuclease of typhoid bacilli and its effect on typhoid bacteriophage nucleic acid. J. gen. Microbiol. 11, 45.

Kovacs, N. (1956). Identification of Pseudomonas pyocyanea by the oxidase reaction. Nature, Lond. 178, 703.

Manual of Microbiological Methods (1957). Ed. by Committee on Bacteriological Technic, Society of American Bacteriologists. New York: MeGraw-Hill.

MARMur, J. (1961). A procedure for the isolation of deoxyribonucleic acid from microorganisms. J. mol. Biol. 3, 208.

Marmur, J. \& Doty, P. (1962). Determination of the base composition of deoxyribonucleic acid from its thermal denaturation temperature. J. mol. Biol. 5, 109.

Marmur, J., Falkow, S. \& Mandel, M. (1963). New approaches to bacterial taxonomy. Annu. Rev. Microbiol. 17, 329.

Marmur, J., Schildoraut, C. L. \& Doty, P. (1961). The reversible denaturation of DNA and its use in studies of nucleic acid homologues and the biological relatedness of microorganisms. J. Chim. phys. p. 945.

Marmur, J., Seaman, E. \& Levine, J. (1963). Interspecific transformation in Bacillus. J. Bact. 85, 461.

McCarthy, B. J. \& Bolton, E. T. (1963). An approach to the measurement of genetic relatedness among organisms. Proc. nat. Acad. Sci., Wash. 50, 156. 
Murray, R. G. E. \& Traunt, J. P. (1954). The morphology, cell structure, and taxonomic affinities of the Moraxella. J. Bact. 67, 13.

OtTolenghi, E. \& Hotchkiss, R. D. (1960). Appearance of genetic transforming activity in pneumoccal cultures. Science, 132, 1257.

Otтolenghi, E. \& Hotchisss, R. D. (1962). Release of genetic transforming agent from pneumococcal cultures during growth and disintegration. J. exp. Med. 116, 491.

Pí́chaud, M. (1961). Le groupe Moraxella. A propos des B5W-Bacterium anitratum. Ann. Inst. Pasteur, 100, suppl. 6, 74.

Ravin, A. W. (1961). The genetics of transformation. Advanc. Genet. 10, 61.

SchaUb, I. G. \& HAUBer, F. D. (1948). A biochemical and serological study of a group of identical unidentifiable Gram-negative bacilli from human sources. J. Bact. 56, 379.

Schildkraut, C. L., Marmur, J. \& Doty, P. (1962). Determination of the base composition of deoxyribonucleic acid from its buoyant density in CsCl. J. mol. Biol. 4, 430.

Sub-committee on the family Neisseriaceae (1954). Preliminary report. Int. Bull. bact. Nomen. Taxon. 4, 95.

Sueoka, N., Marmur, J. \& Doty, P. (1959). Heterogeneity in deoxyribonucleic acids II. Dependence of the density of deoxyribonucleic acids on guanine-cytosine. Nature, Lond. 183, 1429.

TAKAHASHI, I. (1962). Genetic transformation of Bacillus subtilis by extracellular DNA. Biochem. biophys. Res. Commun. 7, 467.

Topley and Wilson's Principles of Bacteriology and Immunity (1955). 4th ed. Ed. by G. S. Wilson\& A. A. Miles. Baltimore: The Williams and Wilkins Co.

Vischer, E. \& ChargafF, E. (1948). The separation and quantitative estimation of purines and pyrimidines in minute amounts. J. biol. Chem. 176, 703.

WyatT, G. R. (1951). The purine and pyrimidine composition of deoxypentosenucleic acids. Biochem. J. 48, 584.

WyatT, G. R. \& Cohen, S. S. (1953). The bases of the nucleic acids of some bacterial and animal viruses: the occurrence of 5-hydroxymethylcytosine. Biochem. J. 55, 774.

ZAMENhof, S. (1957). Preparation and assay of deoxyribonucleic acid from animal tissue. Meth. Enzymol. 3, 702. 